\title{
Pre-service Secondary teachers’ learning styles
}

\author{
R. Sanz Ponce ${ }^{1}$, I. Hernando Mora ${ }^{2}$ \\ 1,2Universidad Católica de Valencia "San Vicente Mártir”
}

\begin{abstract}
Every student copes with his own learning in a particular way and teaching style can determine learning style. This research is developed at a Faculty of Education Sciences where pre-service teachers are being trained. The aim is to analyze the different students' learning styles in the Master for Secondary Teachers' Training. We have used the VARK Questionnaire that includes 4 different learning styles (or sensory modalities): visual, aural, read/write, and kinesthetic. Participants, who were graduated in different degrees, studied in 9 different specialities of the master at Catholic University of Valencia. Results indicated that girls were more likely to prefer a read/write learning style than boys. Furthermore, the most important learning style was aural one, irrespectively of specialities. We conclude that our results can be caused by Master classes, in which students listen to the teacher and teacher explains without a feed-back. Differences among these findings and other researches are discussed.
\end{abstract}

Keywords: Learning styles, teachers, VARK Questionnaire, Master for Secondary Teachers’ Training.

\section{Introduction}

Right to Education is not attending to school but learning (UNESCO, 2013). That means that there must be "learning" to consider the educational process as right (Piaget, 1974), to recognize the right to Education. That is why there are many researches who test teachers' practices and learning processes (Bain, 2006; Jarante y Medina, 2012; Escámez, 2013).

Every student copes with his own learning in a particular way. Knowledge about different learning styles can help to enhance achievement and motivation (Hervás, 2003; Martín y Rodríguez, 2003; Martínez-Fernández y García-Ravidá, 2012), to adapt teaching style in order to enhance educational process.

In this respect, a teacher must think about his own learning style and how this one determines his teaching style. The way in which a teacher learns determine the way in which he teaches. In addition, his styles affect the way in which their students learn (Martínez, 2007).

Learning styles are the strategies or methods which a person uses to learn. These strategies are often stable but they depend on context and activities, and can be raised and changed (Revilla, 1998; Vermunt, 1996). Cognitive, emotional, and physiological features affect the way in which a person responds to the learning (Keefe, 1988). Castro and Guzmán (2005) introduced sociological and psychological factors as features that determine the different styles. Other authors explain that learning styles are a set of variables, half way between intelligence and personality that affect the way of learning (Camarero, Martín y Herrero, 2000). Teachers must bear in mind all of these essential factors to adapt their teaching styles to their students' learning styles (Martínez Geijo, 2007).

The purpose of the present study was to test the students' learning styles in Secondary Teachers' Training Master. 


\section{Material and Methods}

The profile of student's learning preferences was assessed by VARK Questionnaire (Fleming \& Mills, 1992; Fleming, 2006). This Questionnaire provides 16 questions and 4 options for every question because of there are 4 VARK modalities: Visual, Aural, Read/Write and Kinesthetic (Fleming, 1995; Fleming y Baume, 2006). Besides there are multimodal (bi, tri and tetra-modal) learning models, each respondent can choose more than one answer for each of the questions.

Participants were students from Secondary Teachers' Learning Master of the Catholic University of Valencia who were graduated in different degrees (Table 1) at some universities of Valencia (Spain). A total of 9 classes (one class for every speciality) were invited to participate in the investigation. The final sample consisted of 262 students (88,2\% of the total population), $36,7 \%$ male and $63,3 \%$ female. The study was conducted between October and December of 2014.

The data were collected in 15 minutes sessions. An investigator administered the questionnaire to the students and gave instructions to fill out it.

Table 1: Percentage of participants

\begin{tabular}{|c|c|c|c|}
\hline Master for Secondary Teachers’ Training specialities & Enrolment & Participants & $\%$ \\
\hline Business and Economy & 26 & 25 & $96,1 \%$ \\
\hline English & 40 & 34 & $85 \%$ \\
\hline Biology and Geology & 31 & 30 & $96,8 \%$ \\
\hline Physical Education & 34 & 30 & $88.2 \%$ \\
\hline Geography and History & 36 & 25 & $69,4 \%$ \\
\hline Language and Literature & 43 & 40 & $93,0 \%$ \\
\hline Mathematics & 37 & 36 & $97,3 \%$ \\
\hline Technology & 33 & 31 & $94,0 \%$ \\
\hline Educational Guidance & 17 & 13 & $76,5 \%$ \\
\hline TOTAL & 297 & 262 & $88,2 \%$ \\
\hline
\end{tabular}

Frequency analysis, Chi-square tests, and Least Square Means were calculated with SPSS/PC. 


\section{Results and Discussion}

Figure 1 shows the frequency of different modalities. Chi-square analysis did not indicate significant differences between our distribution and a random distribution $(\mathrm{p}=$ 0,0527).

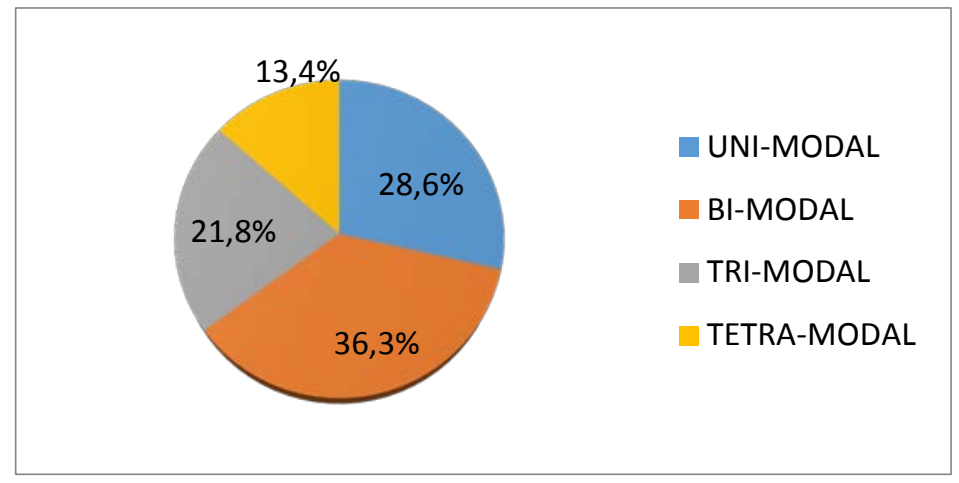

Figure 1. Students' distribution according to modalities.

Table 2 shows that the most frequent uni-modal learning style is the Aural one (58,6\%) and the most frequent bimodal learning style is the AK one.

Table 2. Frequency of different modalities.

\begin{tabular}{lccccccc} 
UNI-MODAL & \multicolumn{2}{c}{ BI-MODAL } & \multicolumn{2}{c}{ TRI-MODAL } & TETRA-IMODAL \\
\hline V weak & 2 & VA & 4 & VAR & 4 & VARK & 35 \\
V strong & 1 & VR & 4 & VAK & 11 & & \\
A weak & 20 & VK & 4 & VRK & 3 & \\
A strong & 24 & AR & 20 & ARK & 39 & \\
R weak & 5 & AK & 44 & & & \\
R strong & 2 & VK & 19 & & & \\
K weak & 11 & & & & & & \\
K strong & 10 & & & & & & \\
\hline TOTAL & 75 & & 95 & & & &
\end{tabular}

According to Horton, Wiederman y Saint (2012) most students have multi-modal styles, irrespective of sex. Wehrwein, Luján y DiCarlo (2006), instead, reported that most girls have uni-modal styles and most boys have multi-modal styles. Because of there are more multi-modal than uni-modal styles, students appear to be less likely to show an uni-modal style. We believe that it is more important to know what the most favourite learning styles of students are. 
Because of the preferences are weaker when combined we have calculated V, A, R, and $\mathrm{K}$ proportions. Each single answer counts as 1.0, each double answer counts as 0,5, each triple answer counts as 0,33 , and each quadruple answer counts as 0,25 . There is not a clearly predominant style: $16,6 \%$ of students are classified as Visual, $32,2 \%$ as Aural, 22,8 Read/Write and 28,4\% as Kinesthetic.

Table 3 gives the percentages of $\mathrm{V}, \mathrm{A}, \mathrm{R}$, and $\mathrm{K}$ profiles and the percentages of unimodal, bi-modal, tri-modal and tetra-modal preferences in every Master speciality.

Tabla 3. Percentages of every learning style and every modality

\begin{tabular}{lcccccccc} 
& \multicolumn{1}{c}{ LEARNING STYLES } & \multicolumn{1}{c}{ MODALITIES } \\
\cline { 2 - 9 } ESPECIALIDAD & $\mathrm{V}$ & $\mathrm{A}$ & $\mathrm{R}$ & $\mathrm{K}$ & $\begin{array}{c}\text { Uni- } \\
\text { modal }\end{array}$ & $\begin{array}{c}\text { Bi- } \\
\text { modal }\end{array}$ & $\begin{array}{c}\text { Tri- } \\
\text { modal }\end{array}$ & $\begin{array}{c}\text { Tetra- } \\
\text { modal }\end{array}$ \\
\hline Business and Economy & $16 \%$ & $36 \%$ & $22 \%$ & $26 \%$ & $24 \%$ & $44 \%$ & $24 \%$ & $8 \%$ \\
English & $16 \%$ & $34 \%$ & $23 \%$ & $27 \%$ & $19 \%$ & $36 \%$ & $26 \%$ & $19 \%$ \\
Biology and Geology & $18 \%$ & $32 \%$ & $21 \%$ & $29 \%$ & $43 \%$ & $24 \%$ & $24 \%$ & $9 \%$ \\
Physical Education & $17 \%$ & $32 \%$ & $24 \%$ & $27 \%$ & $45 \%$ & $31 \%$ & $24 \%$ & $0 \%$ \\
Geography and History & $16 \%$ & $31 \%$ & $22 \%$ & $31 \%$ & $32 \%$ & $20 \%$ & $28 \%$ & $20 \%$ \\
Language and Literature & $14 \%$ & $32 \%$ & $26 \%$ & $28 \%$ & $25 \%$ & $50 \%$ & $12 \%$ & $13 \%$ \\
Mathematics & $19 \%$ & $29 \%$ & $23 \%$ & $29 \%$ & $9 \%$ & $48 \%$ & $26 \%$ & $17 \%$ \\
Tecnology & $16 \%$ & $33 \%$ & $23 \%$ & $28 \%$ & $39 \%$ & $35 \%$ & $13 \%$ & $13 \%$ \\
Educational Guidance & $17 \%$ & $33 \%$ & $20 \%$ & $30 \%$ & $31 \%$ & $23 \%$ & $15 \%$ & $31 \%$ \\
\hline
\end{tabular}

The most frequent modalities are uni-modal and bi-modal ones. The most frequent style is the Aural one at all specialties. This learning style is maximum in Business and Economy (36\%). The least frequent style is the Visual one, whose maximum is $19 \%$ in Mathematics. Kinesthetic style is maximum in Geography and History (31\%). Read/Write style is maximum in Language and Literature speciality, in which Visual style is minimum. Despite that, we did not find significant differences among specialities. The most important one is the Aural style. Furthermore, all the participants are graduated. That means that they are, at least, twenty years old. If we take into account that master class is the most important teaching style in Spain for last few decades in almost any degree, we believe that this teaching style has could determine the students' learning style irrespectively of their initial learning style. According to Revilla (1998) and Vermunt (1996), their learning style has could be changed.

Results from the Least Square Means analysis exploring for possible sex differences, revealed that girls are more likely to prefer a Read/Write style than boys (24,1 and 21,6 per cent, respectively). Horton et al. (2012) reported similar results (28,9 and 25,3 per cent, respectively). Instead, Dobson (2009) found that boys tended to prefer a Read/Write learning more than girls.

There are no more significant differences in the rest of styles. 
Tabla 4. Ls means by sex

\begin{tabular}{lcccc} 
Learning style & Sex & LS Mean & Std Error & $\mathrm{p}$ \\
\hline \multirow{2}{*}{ Visual } & 0 & 16,3639 & 0,9567 & \\
& 1 & 16,6347 & 0,7292 & 0,8221 \\
& 0 & 32,7649 & 1,1958 & \\
Aural & 1 & 32,0072 & 0,9114 & 0,6147 \\
& 0 & 21,5649 & 1,0102 & \\
Read-Write & 1 & 24,0982 & 0,7699 & $0,0471^{*}$ \\
& 0 & 29,3165 & 1,0526 & \\
Kinestthetic & 1 & 27,2766 & 0,8022 & 0,1245 \\
& & &
\end{tabular}

Note. Sex 0 = male, Sex 1 = Female; LS mean = Least Square Means; Std Error = Standard Error; $\mathrm{p}=$ Probability of error; *Significant difference.

\section{Conclusions}

Martínez Geijo (2007) pointed out that teachers generally used the text book and the master class as the only teaching tools. This teaching style has determined the learning style of our students, who got used to learn in a very specific way for fair of fail. According to Rodríguez and Vázquez (2013), learning style of every teacher affects his teaching style which has an influence on his students learning style. Thus, our results can be caused by master classes, in which students listen to the teacher and teacher explains without a feed-back.

\section{References}

Bain, K. (2005). Lo que hacen los profesores de universidad. Valencia: Universidad de Valencia.

Camarero, F.; Martín, F. \& Herrero, J. (2000). Estilos y estrategias de aprendizaje en estudiantes universitarios. Psicothema, vol. 12, n 4, pp. 615-622.

Castro, S. \& Guzmán, B. (2005). Los estilos de aprendizaje en la enseñanza y el aprendizaje: una propuesta para su implementación. Revista de Investigación, 58, pp. 83-102.

Dobson, J. L. (2009) Learning style preferences and course performance in an undegraduate physiology class. Advances in Physiology Education, 33, 308-314.

Escámez, J. (2013). La excelencia en el profesorado universitario. Revista Española de Pedagogía, $n^{\circ}$ 254, pp. 11-27.

Fleming, N. D. (1995). I'm different; not dumb. Modes of presentation (VARK) in the tertiary classroom, in Zelmer, A. (ed.). Research and Development in Higher Education, Proceedings of the 1995 Annual Conference of the Higher Education 
and Research Development Society of Australasia (HERDSA), HERDSA, vol. 18, pp. 308-313.

Fleming, N. D. VARK. A guide to learning styles (on line). http.//www.vark-learn.com

Fleming, N. D. \& Baume, D. (2006). Learning Styles Again: VARKing up the right tree!, Educational Developments, SEDA, Issue 7.4, pp. 4-7.

Hervás, R. M. (2003). Estilos de enseñanza y de aprendizaje en escenarios educativos. Granada: Grupo Editorial Universitario.

Horton, D. M, Wiederman, S. D. y Saint, D. A. (2012). Assessment outcome is weakly correlated with lecture attendance: influence of learning style and use of alternative materials. Advances in Physiology, 36, 105-115.

Jarante, B. \& Medina, J. L. (2012). Saberes docentes y enseñanza universitaria. Estudios sobre Educación, vol. 22, pp. 179-198.

Keefe, J. W. (1988). Development of the NASSP learning style profile. In J. W. Keefe, (ed.): Profiling and utilizing learning style. Reston, Virgina: National Association of Secondary School Principals, pp, 1-21.

Martín, A. V. \& Rodríguez, Mª J. (2003). Estilos de aprendizaje y educación superior. Análisis discriminante en función del tipo de estudios. Enseñanza, 21, pp. 77-97.

Martínez Geijo, P. (2007) Estilos de aprendizaje. AAVV. Aprender y enseñar: Los estilos de aprendizaje y de enseñanza desde la práctica del aula (21-54). Bilbao: Mensajero.

Martínez-Fernández, J. R. \& García-Ravidá, L. (2012). Patrones de aprendizaje en estudiantes universitarios del Máster en Educación Secundaria: variables personales y contextuales relacionadas. Profesorado. Revista de Curriculum y formación del profesorado, vol. 16, nº 1, pp. 165-182.

Piaget, J. (1974). A dónde va la educación. Barcelona: Teide.

UNESCO (2013). Hacia un aprendizaje universal. Lo que cada niño debería aprender. Resumen ejecutivo, Informe $n^{\circ} 1$.

Revilla, D. (1998). Estilos de aprendizaje, in Temas de Educación. www.pucp.edu.pe/temas/estilos.html. (15 de septiembre del 2013).

Rodríguez, Ma . C. \& Vázquez, F. (2013). Fortalecer estilos de aprendizaje para aprender a aprender. Revista Estilos de Aprendizaje, nº 11, vol. 11, pp.19-37.

Vermunt, J. D. (1996). Metacognitive, cognitive and affective aspect of learning styles and strategies: A phenomenographic analysis. Higher Education, 31, pp. 25-50.

Wehrwein, E. A., Luján, H. L. \& DiCarlo S. E. (2006). Gender differences in learning style preferences among undergraduate physiology students. Advances in Physiology Education, 31, 153-157. 